\title{
Impact of Lifestyle Modifications and Paleo Diet on Selected Obese Subjects
}

\author{
P. Indumathy ${ }^{1 *}$ and J. Ramya ${ }^{2}$ \\ 'Associate Professor and Head, Department of Foods and Nutrition, Vellalar College for Women (Autonomous), \\ Erode, Tamilnadu, India; indumathy@vcw.ac.in \\ ${ }^{2}$ M.Phil Research Scholar, Vellalar College for Women, Erode, Tamilnadu
}

\begin{abstract}
Obesity is very common among the higher income groups in India and other developing countries. Paleolithic diet or hunter-gatherer diet is currently popular for weight loss, diabetes management and general well-being. The present study was carried out to assess the nutritional status of the selected obese subjects who followed a modified lifestyle pattern for weight management and a group of subjects who followed paleo diet regularly. The data such as general information and socio-economic background, dietary pattern, anthropometric measurements, clinical, biochemical and biophysical parameters were collected from the selected subjects. Results showed that there is reduction in serum lipid profile except HDL in the subjects who followed lifestyle modifications and paleo diet is not a better choice for sustained weight management.
\end{abstract}

Keywords: Anthropometric Measurements, Lifestyle Modifications, Nutrition Education, Obesity, Paleolithic Diet

\section{Introduction}

Obesity is a global public health problem with major implications for health and the economy. It is a priority in many countries requiring immediate action for prevention and management of obesity. There are a number of trigger points in the life course where individuals gain weight, including the transition from adolescence to adulthood. Obesity is defined as a process characterized by excessive accumulation of body fat with multiple organ specific consequences that could impair health 1 .

Management of overweight patients focuses primarily on lifestyle changes such as diet, physical activity, sleep and stress reduction. A combination of physical activity and dietary changes has been found to be most effective for weight loss. If these measures are unsuccessful after six months, then medications, surgery, and other referrals may be required 2 .

The paleo diet aims to mimic what humans were eating prior to the advent of agriculture some 10,000 years ago. Before food scarcity was eliminated in many parts of the world, diet was not a choice but rather the outcome itself. The never-ending quest for enough calories to survive generally meant that people would eat anything they could get their hands on, and the only weight loss connected to diet came in the form of starvation. Therefore, the Paleo Diet falls somewhere in the middle ${ }^{3}$. The paleo diet lessens the body's glycemic load, has a healthy ratio of saturatedto-unsaturated fatty acids, increases vitamin and nutrient consumption, and contains an optimal balance of protein, fat and carbohydrates ${ }^{4}$.

The present study was carried out with the objectives to assess the nutritional status of the selected obese subjects and to evaluate the impact of lifestyle modifications and

${ }^{*}$ Author for correspondence 
paleo diet among selected obese subjects.

\section{Materials and Methods}

\subsection{Selection of Subjects}

Fifty obese subjects (BMI $>30)$ in the age group of 20 to 50 years and without major complications like diabetes, hypertension, hypercholesterolemic and other degenerative diseases were selected by convenience sampling. The paleo diet includes fleshy foods, eggs, greens, vegetables, dairy products and eliminates the cereals and pulses. The control group (10 subjects) were advised to follow their regular lifestyle. The subjects of experimental group I (20 subjects) were advised to take the above paleo foods. They followed vegetarian, non-vegetarian and ova-vegetarian paleo foods according to the availability, the experimental group II (20 subjects) were advised to follow lifestyle modifications like reduced calorie intake, increased physical activity and behavioral interventions.

\subsection{General Information and Socio-}

\section{Economic Status}

An interview schedule was used to elicit information on general and socio-economic status such as name, age, sex, marital status, type of work, education level, family income and type of family from all the selected subjects.

\subsection{Dietary Survey}

The details regarding the dietary pattern were collected from all the selected subjects by 24- hour recall method for three consecutive days to study the food and nutrient intake of the obese subjects before and after the study period.

\subsection{Anthropometric Measurements}

Height, weight, waist circumference and hip circumference of all the 50 selected subjects were measured using standard procedures. With the help of this data Body Mass Index (BMI) and Waist Hip Ratio (WHR) were estimated.

\subsection{Clinical Assessment}

The obese subjects were examined clinically for the presence of nutritional deficiency disease such as eyes, hair, mouth, skin, face, poor appetite, nausea and vomiting, constipation, oedema, diarrhea, eclampsia, heartburn, toxemia and fatigue with the help of a physician.

Table 1. Mean initial and final weights of the selected subjects

\begin{tabular}{|c|c|c|c|c|}
\hline \multirow{2}{*}{ Groups } & \multicolumn{2}{|c|}{ Mean Weight(kg) } & \multirow{2}{*}{$\begin{array}{c}\text { Difference } \\
(\mathbf{k g})\end{array}$} & \multirow{2}{*}{ 't' value } \\
\cline { 2 - 3 } & Initial & Final & 1.45 & $3.83^{\star *}$ \\
\hline Control $(\mathbf{n = 1 0})$ & $87.25 \pm 13.73$ & $88.7 \pm 14.02$ & -10.55 & $25.72^{\star *}$ \\
\hline Experimental group I $(\mathbf{n = 2 0})$ & $78 \pm 7.43$ & $67.45 \pm 7.22$ & -7.5 & $13.38^{\star *}$ \\
\hline Experimental group II $(\mathbf{n}=\mathbf{2 0})$ & $80.7 \pm 5.92$ & $73.2 \pm 6.66$ & \\
\hline
\end{tabular}

**-significant at $1 \%$ level

Table 2. Mean BMI of the selected subjects before and after the study period

\begin{tabular}{|c|c|c|c|c|}
\hline \multirow{2}{*}{ Groups } & \multicolumn{2}{|c|}{ Mean BMI } & \multirow{2}{*}{ Difference } & \multirow{2}{*}{ 't' value } \\
\cline { 2 - 5 } & Initial & Final & & \\
\hline Control $(\mathbf{n = 1 0})$ & $32.95 \pm 1.41$ & $34.23 \pm 1.93$ & 1.28 & \multirow{2}{*}{$4.44^{\star *}$} \\
\hline Experimental group I $(\mathbf{n = 2 0})$ & $30.48 \pm 0.70$ & $25.96 \pm 1.60$ & -4.52 & $15.38^{\star *}$ \\
\hline Experimental group II $(\mathbf{n}=\mathbf{2 0})$ & $30.62 \pm 0.83$ & $27.72 \pm 1.22$ & -2.9 & $13.38^{\star *}$ \\
\hline
\end{tabular}

**- significant at $1 \%$ level 


\subsection{Biochemical Assessment}

The subjects were asked to come early morning in empty stomach on $1^{\text {st }}$ day to do pretest for lipid profile and fasting blood glucose level. Similarly post test was conducted after 90 days.

\subsection{Biophysical Measurement}

Blood pressure of all the selected 50 subjects was measured on the inside of an elbow at the brachial artery, upper arm's major blood vessel that carries blood away from the heart using a sphygmomanometer.

\subsection{Development of Educational Module for} Obese Subjects

The selected subjects were provided nutrition education for about three hours at initial stage of the study using the developed aids such as posters, folders, charts and simple physical exercise at Sri Kumaran Diabetic
Clinic, Chennimalai and Sri Durga Hospital, Ingur.

\section{Results and Discussions}

The data collected from the selected subjects were analysed and discussed.

\subsection{Weight}

Table 1 gives the comparison of the initial and final weight of the selected obese subjects in the control and experimental groups.

It is evident that there was considerable reduction in mean weight (at $1 \%$ level) of both experimental group I and experimental group II but in the control group there was significant increase in weight (at $1 \%$ level) after the study period of 90 days. The reduction of weight may be due to the paleo diet in experimental group I and lifestyle modifications in experimental group II. Intake of paleo diet showed greater reduction of weight in obese subjects

Table 3. Mean waist circumference before and after the study

\begin{tabular}{|c|c|c|c|c|}
\hline \multirow{2}{*}{ Groups } & \multicolumn{2}{|c|}{$\begin{array}{l}\text { Mean Waist circumference } \\
\qquad(\mathrm{cm})\end{array}$} & \multirow{2}{*}{ Difference $(\mathrm{cm})$} & \multirow{2}{*}{ 't' value } \\
\hline & Initial & Final & & \\
\hline Control $(n=10)$ & $102.8 \pm 8.43$ & $103.7 \pm 8.25$ & 0.9 & $2.8^{*}$ \\
\hline Experimental group I ( $n=20)$ & $99.95 \pm 5.82$ & $94.5 \pm 5.88$ & -5.45 & $30.74^{* *}$ \\
\hline Experimental group II $(n=20)$ & $100.6 \pm 10.01$ & $95.95 \pm 10.14$ & -4.65 & $19.32^{* *}$ \\
\hline
\end{tabular}

** - significant at $1 \%$ level $\quad{ }^{\star}$ - significant at $5 \%$ level

Table 4. Mean waist hip ratio of the selected subjects before and after the study

\begin{tabular}{|c|c|c|c|c|}
\hline \multirow{2}{*}{ Groups } & \multicolumn{2}{|c|}{ Mean WHR } & \multirow{2}{*}{ Difference } & \multirow{2}{*}{ 't' value } \\
\cline { 2 - 3 } & Initial & Final & & - \\
\hline Control $(\mathbf{n = 1 0})$ & $0.89 \pm 0.05$ & $0.89 \pm 0.05$ & 0 & $4.15^{\star *}$ \\
\hline Experimental group I ( $\mathbf{n = 2 0})$ & $0.89 \pm 0.03$ & $0.87 \pm 0.03$ & -0.02 & $1.26^{\mathrm{NS}}$ \\
\hline Experimental group II $(\mathbf{n}=\mathbf{2 0})$ & $0.90 \pm 0.04$ & $0.89 \pm 0.05$ & -0.01 & \multirow{2}{*}{} \\
\hline
\end{tabular}

${ }^{* *}$ - significant at $1 \%$ level NS - Not significant 
than lifestyle modifications.

\section{$3.2 \mathrm{BMI}$}

Table 2 reveals that mean BMI of all the three groups are more than 30 initially and are in the range of Grade-II obesity (BMI between 30-40).

The data clearly indicates that the mean BMI of the selected subjects of experimental group I before following Paleo diet was 30.48 which was reduced to 25.96 after the study period (at $1 \%$ level). Similarly the mean BMI of the selected subjects of experimental group II before following lifestyle modifications and diet was 30.62 which was reduced to 27.72 after the study period of 90 days (at $1 \%$ level). This may be due to the reduced intake and increased physical activity of the group.

\subsection{Waist Circumference}

Waist circumference is the most practical tool a clinician can use to evaluate a patient's abdominal fat before and during weight loss treatment. The mean waist circumference before the study in all the three groups is greater than $88 \mathrm{~cm}$ in female and $102 \mathrm{~cm}$ in male ( > normal range) who are at high risk waist circumference.

Table 3 indicates that there was considerable reduction in mean waist circumference in experimental group I and experimental group II (at $1 \%$ level). But in control group, the final mean waist circumference had increased significantly at $5 \%$ level. The reduction in mean waist circumference is more in experimental group I $(5.45 \mathrm{~cm})$ than in experimental group II $(4.65 \mathrm{~cm})$ which shows that paleo diet was more effective than lifestyle modifications.

\subsection{Waist-Hip Ratio (WHR)}

Table 4 indicates the mean waist-hip ratio of all the three groups of control group, experimental group I and experimental group II before and after the study.

Table 4 shows that there is significant reduction (at $1 \%$ level) in mean waist-hip ratio in experimental group I who followed paleo diet and there is no significant reduction in experimental group II who followed lifestyle modifications. But there is no reduction in mean WHR in control group. The experimental group I shows significant reduction in waist-hip ratio compared to experimental group II.

\subsection{Health Status}

General health status was assessed for the selected subjects to find out the presence of any health problems in the selected subjects.

Table 5. Health status of the selected subjects $(\mathrm{N}=50)$

\begin{tabular}{|c|c|c|}
\hline Disorders & Number & Per cent \\
\hline \multicolumn{3}{|l|}{ Blood pressure } \\
\hline High & - & - \\
\hline Low & 8 & 16 \\
\hline Normal & 42 & 84 \\
\hline \multicolumn{3}{|l|}{ Respiratory disorders } \\
\hline Bronchitis & 5 & 10 \\
\hline Asthma & 4 & 8 \\
\hline Nil & 41 & 82 \\
\hline \multicolumn{3}{|l|}{ Gastrointestinal disorders } \\
\hline Gastric ulcer & 7 & 14 \\
\hline Stomach pain & 8 & 16 \\
\hline Constipation & 14 & 28 \\
\hline Nil & 21 & 42 \\
\hline Arthritis & 30 & 60 \\
\hline Nil & 20 & 40 \\
\hline Other complications & - & - \\
\hline
\end{tabular}

From Table 5 it is understood that 16 per cent of the subjects had low blood pressure, 18 per cent of the subjects had respiratory disorders, 14 per cent had gastric ulcer, 16 per cent had stomach pain, 28 per cent had constipation and 60 per cent had arthritis. The selected subjects did not have any other major health problems like diabetes, hypertension, hypercholesterolemia and other degenerative diseases.

\subsection{Dietary Pattern of the Selected Subjects}

\subsubsection{Nature of Diet}

Table 6 revealed that 60 per cent of the control group, 60 per cent of experimental group I and 65 per cent of experimental group II were non-vegetarians. 40 per cent of experimental group I, 30 per cent of experimental group II and 20 per cent of control group were vegetarians. 20 per cent of control group and five per cent of experimental group II were ova-vegetarians. Here among the selected 
Table 6. Type of diet of the selected subjects

\begin{tabular}{|c|c|c|c|c|c|c|}
\hline \multirow[b]{2}{*}{ Type of diet } & \multicolumn{2}{|c|}{ Control group } & \multicolumn{2}{|c|}{ Experimental group I } & \multicolumn{2}{|c|}{ Experimental group II } \\
\hline & Number & Per cent & Number & Per cent & Number & Per cent \\
\hline Vegetarian & 2 & 20 & 8 & 40 & 7 & 30 \\
\hline & 6 & 60 & 12 & 60 & 13 & 65 \\
\hline Ova-vegetarian & 2 & 20 & - & - & 1 & 5 \\
\hline Total & 10 & 100 & 20 & 100 & 20 & 100 \\
\hline
\end{tabular}

Table 7. Mean nutrient intake of the selected subjects before and after the study

\begin{tabular}{|c|c|c|c|c|c|c|c|c|c|c|}
\hline Groups & \multicolumn{2}{|c|}{ Energy (Kcal) } & \multicolumn{2}{|c|}{ Protein (gm) } & \multicolumn{2}{|c|}{ Fat (gm) } & \multicolumn{2}{|c|}{ Fibre (gm) } & \multicolumn{2}{|c|}{ Vit C (mg) } \\
\hline RDA & \multicolumn{2}{|c|}{2425} & \multicolumn{2}{|c|}{60} & \multicolumn{2}{|c|}{20} & \multicolumn{2}{|c|}{25} & \multicolumn{2}{|c|}{40} \\
\hline \multirow{2}{*}{$\begin{array}{c}\text { Control } \\
\text { group }(n=10)\end{array}$} & Initial & Final & Initial & Final & Initial & Final & Initial & Final & Initial & Final \\
\hline & $\begin{array}{c}3376 \pm \\
452\end{array}$ & $\begin{array}{c}3405 \pm \\
426\end{array}$ & $\begin{array}{c}78.91 \pm \\
14.09\end{array}$ & $\begin{array}{c}78.12 \pm \\
14.91\end{array}$ & $\begin{array}{c}53.3 \pm \\
3.07\end{array}$ & $\begin{array}{c}51.52 \pm \\
2.56\end{array}$ & $\begin{array}{c}27.95 \pm \\
1.67\end{array}$ & $28.25 \pm 2.37$ & $\begin{array}{c}47.4 \pm \\
4.62\end{array}$ & $\begin{array}{c}48.4 \pm \\
4.84\end{array}$ \\
\hline Difference & \multicolumn{2}{|c|}{29} & \multicolumn{2}{|c|}{-0.79} & \multicolumn{2}{|c|}{-1.78} & \multicolumn{2}{|c|}{0.3} & \multicolumn{2}{|c|}{1.0} \\
\hline 't' value & \multicolumn{2}{|c|}{$2.23^{\mathrm{NS}}$} & \multicolumn{2}{|c|}{$0.11^{\mathrm{NS}}$} & \multicolumn{2}{|c|}{$2.22^{\mathrm{NS}}$} & \multicolumn{2}{|c|}{$0.20^{\mathrm{NS}}$} & \multicolumn{2}{|c|}{$1.07^{\mathrm{NS}}$} \\
\hline \multirow{2}{*}{$\begin{array}{l}\text { Experimen- } \\
\text { tal group I } \\
\quad(n=20)\end{array}$} & Initial & Final & Initial & Final & Initial & Final & Initial & Final & Initial & Final \\
\hline & $\begin{array}{c}3405 \pm \\
305\end{array}$ & $\begin{array}{c}2807 \pm \\
84\end{array}$ & $\begin{array}{c}80.93 \pm \\
8.03\end{array}$ & $\begin{array}{c}178.12 \pm \\
6.34\end{array}$ & $\begin{array}{c}51.49 \pm \\
2.49\end{array}$ & $\begin{array}{c}86.88 \pm \\
6.88\end{array}$ & $\begin{array}{c}30.45 \pm \\
3.85\end{array}$ & $\begin{array}{c}24.45 \pm \\
2.35\end{array}$ & $46.6 \pm 3.13$ & $\begin{array}{c}42.75 \pm \\
1.59\end{array}$ \\
\hline Difference & \multicolumn{2}{|c|}{-598} & \multicolumn{2}{|c|}{97.19} & \multicolumn{2}{|c|}{35.49} & \multicolumn{2}{|c|}{-6} & \multicolumn{2}{|c|}{-3.85} \\
\hline 't'value & \multicolumn{2}{|c|}{$8.60^{* *}$} & \multicolumn{2}{|c|}{$36.17^{\star *}$} & \multicolumn{2}{|c|}{$19.71^{\star *}$} & \multicolumn{2}{|c|}{$6.26^{* *}$} & \multicolumn{2}{|c|}{$4.27^{\star *}$} \\
\hline \multirow{2}{*}{$\begin{array}{l}\text { Experimen- } \\
\text { tal group II } \\
\quad(n=20)\end{array}$} & Initial & Final & Initial & Final & Initial & Final & Initial & Final & Initial & Final \\
\hline & $\begin{array}{c}3624 \pm \\
232\end{array}$ & $\begin{array}{c}2570 \pm \\
199\end{array}$ & $\begin{array}{c}87.36 \pm \\
7.72\end{array}$ & $\begin{array}{c}54.92 \pm \\
2.05\end{array}$ & $\begin{array}{c}50.99 \pm \\
2.78\end{array}$ & $\begin{array}{c}41.01 \pm \\
2.44\end{array}$ & $\begin{array}{c}29.37 \pm \\
3.54\end{array}$ & $\begin{array}{c}46.15 \pm \\
1.95\end{array}$ & $\begin{array}{c}47.15 \pm \\
3.57\end{array}$ & $\begin{array}{c}48.55 \pm \\
3.57\end{array}$ \\
\hline Difference & \multicolumn{2}{|c|}{-1053} & \multicolumn{2}{|c|}{-32.44} & \multicolumn{2}{|c|}{-9.98} & \multicolumn{2}{|c|}{16.98} & 1 & \\
\hline 't'value & 15. & & 20. & & & & & $24^{* *}$ & 1.5 & \\
\hline
\end{tabular}

RDA- Recommended dietary allowance (ICMR, 2010)ํ.

**-Significant at $1 \%$ level NS - Not significant 
fifty obese subjects, most of the subjects (65\%) were having the habit of taking non-vegetarian foods which are calorie dense, rich in fat and cholesterol which is not good for healthy well being.

\subsubsection{Nutrient Intake of Selected Subjects}

Twenty four hour recall method for three days was carried to study the nutrient intake of the selected 50 obese subjects. The nutrient intake (Energy, Protein, Fat, Fibre, Vitamin C) of the selected obese subjects were calculated using the food composition table given by Gopalan et al. $(2011)^{\underline{5}}$.

Information regarding the nutrient intake of the selected subjects were compared with RDA and are given in Table 7.

Table 7 shows that the mean energy intake, protein intake and fat intake of all the selected subjects of control group, experimental group I and experimental group II were greater than RDA before the study. But the mean fibre intake was less than the recommended intake in all the three groups. This shows that excess of nutrient intake would have caused obesity in the selected subjects.
There was significant reduction in mean energy intake, protein intake and fat intake during the study in experimental group II (at $1 \%$ level) compared to experimental group I. There was increased intake of fibre in experimental group II who followed lifestyle modifications than experimental group I who followed paleo diet. There was no significant change in mean intake of any of the nutrients in control group.

But in the experimental group I who followed paleo diet, the mean protein and fat intake was higher than RDA compared to experimental group II (significant at $1 \%$ level). The mean energy intake in experimental group I was also reduced during the study period (significant at $1 \%$ level).

\subsubsection{Serum Cholesterol}

Table 8 indicates the mean serum cholesterol levels of control and experimental groups I and II before and after the study.

The normal range of serum cholesterol is 130 to 200 $\mathrm{mg} / \mathrm{dl}$ (www.nhlbi.nih.gov) ${ }^{7}$. Table 8 reveals that the mean cholesterol of experimental group II had decreased after

Table 8. Comparison of mean serum cholesterol before and after the study

\begin{tabular}{|c|c|c|c|c|}
\hline \multirow[t]{2}{*}{ Groups } & \multicolumn{2}{|c|}{ Mean cholesterol level ( mg / dl ) } & \multirow[t]{2}{*}{ Difference mg / dl } & \multirow[t]{2}{*}{ 't' value } \\
\hline & Initial & Final & & \\
\hline Control $(n=10)$ & $182.4 \pm 7.40$ & $176.9 \pm 7.42$ & -5.5 & $9.77^{\star *}$ \\
\hline Experimental group I ( $n=20$ ) & $186.9 \pm 6.85$ & $229.6 \pm 10.69$ & 42.5 & $17.63^{\star *}$ \\
\hline Experimental group II $(\mathrm{n}=20)$ & $187.8 \pm 6.25$ & $158.95 \pm 9.49$ & -28.85 & $11.34^{* *}$ \\
\hline
\end{tabular}

$* *$ - Significant at $1 \%$ level

Table 9. Comparison of mean serum triglyceride before and after the study

\begin{tabular}{|c|c|c|c|c|}
\hline \multirow{2}{*}{ Groups } & \multicolumn{2}{|c|}{ Mean triglyceride level $(\mathbf{m g} / \mathbf{d l})$} & \multirow{2}{*}{$\begin{array}{c}\text { Difference } \mathbf{~ m g} \\
/ \mathbf{d l}\end{array}$} & \multirow{2}{*}{ 't' value } \\
\cline { 2 - 4 } & Initial & Final & -41.9 & $11.21^{* *}$ \\
\hline Control $(\mathbf{n = 1 0})$ & $132.3 \pm 11.47$ & $90.4 \pm 3.86$ & 99.2 & $14.72^{* *}$ \\
\hline Experimental group I ( $\mathbf{n = 2 0})$ & $140.15 \pm 4.28$ & $239.35 \pm 30.50$ & -54.65 & $13.64^{* *}$ \\
\hline
\end{tabular}

** - Significant at $1 \%$ level 
following lifestyle modifications (significant at $1 \%$ level). But there was significant increase in the mean serum cholesterol in the control group at $1 \%$ level. Experimental group I showed significant increase in the mean serum cholesterol at the end of study period (at 1\% level) which was above the desirable level. This proves that the increase in serum cholesterol is due to the paleo diet as it is rich in saturated fatty acids.

\subsubsection{Serum Triglyceride}

Table 9 indicates the mean serum triglyceride levels of control and experimental groups before and after the study.

The normal range of serum triglyceride is 50 to 170 $\mathrm{mg} / \mathrm{dl}$ (www.nhlbi.nih.gov) ${ }^{7}$. The Table 9 reveals that the mean serum triglyceride level of experimental group II had decreased significantly (at 1\% level) after following lifestyle modifications. There was also significant reduction in the serum triglyceride in the control group. Experimental group I showed significant increase in the serum triglyceride (at $1 \%$ level) which was above the normal range. This proves that the increase in serum triglyceride is due to the paleo diet as it is rich in saturated fatty acids.

\subsubsection{Serum HDL}

Table 10 indicates the mean serum HDL levels of control and experimental groups before and after the study.

HDL cholesterol is a good cholesterol which reduces the risk of heart diseases ${ }^{8}$. The mean serum HDL levels were found to be in the normal range of 35 to $55 \mathrm{mg} / \mathrm{dl}$ (www.nhlbi.nih.gov) ${ }^{7}$, before the study in all the three groups of control group, experimental group I and experimental group II.

The table reveals that the mean serum HDL level of experimental group II had increased significantly (at $1 \%$ level) after following lifestyle modifications. There was no significant increase in the serum HDL in the control group. Experimental group I showed significant reduction in the serum HDL (at 1\% level). This proves that the decrease in serum HDL is due to the paleo diet.

\subsubsection{Serum LDL}

Table 11 indicates the mean serum LDL levels of control and experimental groups before and after the study.

The normal range of serum LDL is 40 to $140 \mathrm{mg} / \mathrm{dl}$

Table 10. Comparison of mean serum HDL before and after the study

\begin{tabular}{|c|c|c|c|c|}
\hline \multirow{2}{*}{ Groups } & \multicolumn{2}{|c|}{ Mean HDL level ( mg / dl ) } & \multirow{2}{*}{$\begin{array}{c}\text { Difference mg } \\
\text { / dl }\end{array}$} & \multirow{2}{*}{ 't' value } \\
\hline & Initial & Final & & \\
\hline Control group $(n=10)$ & $40.6 \pm 2.91$ & $41.1 \pm 3.07$ & 0.5 & \\
\hline Experimental group I ( $n=20)$ & $42.35 \pm 5.02$ & $35 \pm 3.34$ & -7.35 & $11.38^{* *}$ \\
\hline Experimental group II $(\mathrm{n}=20)$ & $42 \pm 4.02$ & $48.7 \pm 1.56$ & 6.7 & $15.11^{\star *}$ \\
\hline
\end{tabular}

** - Significant at $1 \%$ level NS - not significant

Table 11. Comparison of mean serum LDL before and after the study

\begin{tabular}{|c|c|c|c|c|}
\hline \multirow{2}{*}{ Groups } & \multicolumn{2}{|c|}{ Mean LDL level } & \multirow{2}{*}{ Difference } & \multirow{2}{*}{ 't' value } \\
\cline { 2 - 5 } & \multicolumn{2}{|c|}{ Initial } & Final $/ \mathrm{dl}$ & \\
\hline Control $(\mathbf{n}=\mathbf{1 0})$ & $92.1 \pm 4.53$ & $128.7 \pm 12.05$ & 36.6 & \multirow{2}{*}{$9.45^{* *}$} \\
\hline Experimental group I $(\mathbf{n = 2 0})$ & $90.15 \pm 4.59$ & $188.55 \pm 21.29$ & 98.4 & $22.27^{* *}$ \\
\hline Experimental group II $(\mathbf{n}=\mathbf{2 0})$ & $90.7 \pm 4.59$ & $67.1 \pm 8.40$ & -23.6 & $12.40^{* *}$ \\
\hline
\end{tabular}

** Significant at $1 \%$ level 
(www.nhlbi.nih.gov). The reduction in serum LDL level of experimental group II (significant at $1 \%$ level) shows that lifestyle modifications will reduce the serum LDL level. But there was a huge increase in the mean serum LDL level in experimental group I (who followed paleo diet) above the desirable level who followed Paleo diet (significant at $1 \%$ level). This shows that intake of paleo diet will increase the serum LDL which may lead to cardiac diseases.

LDL is called 'bad cholesterol' because it causes atherosclerosis. Long term intake of paleo diet may elevate the serum LDL levels and develop atheroma. This is due to high level of saturated fatty acid in paleo diet which increases plasma cholesterol and promotes the formation of atheroma ${ }^{8}$.

\section{Conclusion}

The paleo diet generally includes fleshy foods, milk, nuts, eggs, greens and vegetables and eliminates the whole cereals and pulses. There is no calorie limitation in paleo diet. One can take these foods to their satiety level. In the present study though there is weight reduction on intake of paleo diet, there is great elevation of serum cholesterol, triglycerides, LDL and VLDL which may lead to cardiac disorders. Low carbohydrate intake may lead to ketosis and severe metabolic abnormalities. High protein and fat intake is not advisable for long term health benefits.

But, there is reduction in serum lipid profile except HDL in the subjects who followed lifestyle modifications like reduced calorie intake, regular physical activity and behavioral interventions. Increased intake of fibre and reduced fat in modified diet did not have any adverse effect in their biochemical reports. Since there is no adverse effect of lifestyle modifications, obese subjects can follow this for health benefits and reduction of weight. So lifestyle modifications can be recommended to reduce the weight and serum lipid levels in obese subjects.

\section{References}

1. Poobalan A. Prevention of obesity: exploration of lifestyle in 18-25 year olds. The Authors Journal compilation @ 2009 International Association for the Study of Obesity. 2011; p. 4.

2. Glickman D and Parker L. Committee on Accelerating Progress in Obesity Prevention. National Academics Press. 2012.

3. Hawks and John. Evolutionary biology: Twisting the tale of human evolution. Nature. 2013; 495:172. https://doi.org/10.1038/495172a

4. Stevens J, McClain JE and Truesdale KP. Selection of measures in epidemiologic studies of the consequences of obesity. International Journal of Obesity. 2016; 32:6.

5. Gopalan C, Ramasastri BV and Balasubramanium SC. Nutritive Value of Indian Foods. Indian Council of Medical Research, Hyderabad, India. 2011; p. 68. PMid:20970164

6. ICMR. Nutrient requirements and recommended dietary allowances for Indians. A report of the expert group of Indian Council of Medical Research. 2010.

7. Available from: www.nhlbi.nih.gov.

8. Srilakshmi B. Nutrition Science. New Age International (P) Limited Publishers, 4th edition. 2014; p. 380-445. 